\title{
Association of serum vitamin D levels with gestational diabetes mellitus
}

\author{
Sharmeen Mahmood*, Hasna Hena Pervin, Shereen Yousuf
}

Department of Obstetrics and Gynecology, Bangabandhu Sheikh Mujib Medical University, (BSMMU), Dhaka, Bangladesh

Received: 28 March 2021

Accepted: 30 April 2021

\section{*Correspondence:}

Dr. Sharmeen Mahmood,

E-mail: dr.sharmeenmahmood30@gmail.com

Copyright: () the author(s), publisher and licensee Medip Academy. This is an open-access article distributed under the terms of the Creative Commons Attribution Non-Commercial License, which permits unrestricted non-commercial use, distribution, and reproduction in any medium, provided the original work is properly cited.

\section{ABSTRACT}

Background: This study was done to evaluate the association of serum vitamin D level with GDM ( $\mathrm{n}=30$ ) and without $\operatorname{GDM}(n=30)$. The age and body mass index of the participants along with their gestational age, gravidity and parity were harmonized. The serum vitamin D levels and blood glucose were investigated. The results revealed that, normal pregnant women had significantly higher vitamin D level than their GDM counterparts.

Methods: This case-control study was conducted on healthy pregnant women attending routine antenatal care at Bangabandhu Sheikh Mujib medical university from January 2019 to December 2019 recruited at third trimester of gestation. We measured maternal serum vitamin D status $(25[\mathrm{OH}] \mathrm{D})$ in third trimester of pregnancy. GDM was diagnosed according to the American diabetes association. guidelines. Vitamin D status was defined as, vitamin D sufficiency ( $\geq 30$ or $\geq 75 \mathrm{nmol} / \mathrm{L}$ ), insufficiency $(20-30$ and $50-75 \mathrm{nmol} / \mathrm{L}$ ), were used to categories participants according to their $25[\mathrm{OH}] \mathrm{D}$ concentrations. We calculated adjusted odds ratios and $95 \%$ confidence intervals (CIs) using logistic regression.

Results: The mean serum vitamin D level was lower in case group case $23.4(17.4 \pm 35.1)$ compared to that in control group $29.7(15.4 \pm 39.8)$ and the difference between the 2 groups was statistically significant $(\mathrm{p} \leq 0.001)$. Sufficient level of vitamin D was more in control group $(66.7 \%)$ than that of case group $(26.1 \%)$. Insufficient level of vitamin D was higher in case $(73.3 \%)$ group than that of control $(33.3 \%)$ group. These findings were significant $(\mathrm{p}=0.021)$. Respondents with insufficient level of vitamin D have 3.1 times more chance to develop GDM.

Conclusions: Serum vitamin D level is reduced in pregnant women having GDM.

Keywords: Vitamin D, Gestational diabetes mellitus, Pregnancy

\section{INTRODUCTION}

Vitamin D is a fat-soluble substance which after activation becomes hormone. ${ }^{1}$ This vitamin is found in two forms; vitamin D2 or ergocalciferol which is manufactured by plants or fungus and vitamin D3 or cholecalciferol which is the most effective form in human body. ${ }^{1}$ Vitamin D plays significant role in bone mineralization through the maintenance of calcium and phosphorus homeostasis. ${ }^{2}$ Several evidence suggests that vitamin D influences several pathophysiological processes and is also known to modulate both innate and adaptive immunity. ${ }^{3}$ Vitamin D deficiency is responsible for the risk of several chronic diseases, such as diabetes mellitus and cardiovascular diseases ${ }^{4}$.Hypovitaminosis D is highly prevalent among pregnant women. ${ }^{5,6}$ Several important functions in pregnancy, including glucose homeostasis, placental function, inflammatory response and infection control has been linked with Vitamin D. ${ }^{7}$ Increases the risk of adverse pregnancy outcomes, such as preeclampsia, gestational diabetes mellitus and small-for-gestational-age is related with vitamin D deficiency. ${ }^{8,9}$ Macrosomia, birth trauma, respiratory distress syndrome, jaundice, hypoglycemia, an increased rate of primary cesarean section , preterm labor, are the complications of infant of mother with GDM. ${ }^{10}$ Infants of mothers with GDM are at a higher risk of obesity 
and diabetes in later life compared to their unexposed siblings. In addition, GDM is also related with a high risk of the development of diabetes in these women in later life. ${ }^{11,12}$ Several studies have shown associations between maternal serum vitamin D concentrations in the $1^{\text {st }}$ or early $2^{\text {nd }}$ trimester and the development of GDM. ${ }^{13-15}$ These findings were supported by a meta-analysis of observational studies that indicated a consistent association between vitamin D deficiency and an increased risk of maternal GDM. ${ }^{16}$ Patients having GDM have significantly low vitamin D level than normal counterparts and responsible for development of type 2 diabetes in GDM mothers. Given the high prevalence of vitamin D (70-100\%) deficiency in developing countries, especially in Asian pregnant women and evidence that vitamin D supplementation in gestational diabetes patients had beneficial effects on fasting plasma glucose and serum

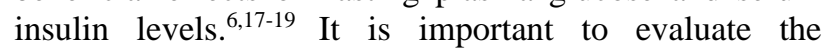
association of GDM with this condition of high vitamin D deficiency in these countries. Therefore, this study, was conducted in an ongoing prospective observational on healthy pregnant women to examine the relationship between vitamin D levels and GDM status during pregnancy.

\section{METHODS}

This case-control study was performed at the department of obstetrics and gynecology of Bangabandhu Sheikh Mujib medical university from January 2019 to December 2019. The eligibility criteria for the study included pregnant women aged 18 to 40 years registering for antenatal screening in their third trimester planning to deliver at study institution. Women with multiple fetuses, chronic illness, diabetes mellitus, hypertension, cardiac disease, or thyroid disease were excluded from the study. At recruitment the demographic and anthropometric variables studied were age, socio-economic status, weight, educational qualification, occupation, family history of diabetes, maternal body mass index (BMI). The obstetrical variables were gestational age, gravida, parity and biochemical parameters were measurement of serum 25(OH)D, fasting blood sugar Blood sugar 2 hours following $75 \mathrm{gm}$ oral glucose load. All pregnant women attending antenatal clinics are screened using a 75-gm oral glucose. GDM was defined according to the recommend actions of the American diabetes association (ADA) such that women were diagnosed with GDM if two or more of the following exceeded ADA criteria after a 75-gm oral glucose tolerance test: fasting $\geq 5.3 \mathrm{mmol} / \mathrm{L}(95 \mathrm{mg} / \mathrm{dL}) ; 2$ $\mathrm{h} \geq 8.6 \mathrm{mmol} / \mathrm{L}$ (155 mg/dL). ${ }^{20}$ According to previously published criteria, vitamin D sufficiency $(\geq 30 \mathrm{ng} / \mathrm{mL}$ or $\geq 75 \mathrm{nmol} / \mathrm{L})$, insufficiency (20-30 ng/mL, 50-75 nmol/L), were used to categories participants according to their $25[\mathrm{OH}] \mathrm{D}$ concentrations gestational age (in weeks) was calculated from the last date of the menstrual cycle and confirmed through ultrasonography. ${ }^{4} 5 \mathrm{ml}$ of blood was taken from antecubital vein. Serum vitamin D level was measured by chemiluminescence micro particles immunoassay method (CM1A) in Abbott architect system.
Serum $25(\mathrm{OH})$ D levels of all study participants were measured. Data were analyzed by using computer software SPSS (Statistical package for social sciences, version 23) and statistical analysis was performed by Chi-squared $\left(\chi^{2}\right)$ test for the comparison of data presented in categorical scale and two-tailed Student's t-test for comparison of data presented on a continuous scale. The $\mathrm{p}<0.05$ was considered statistically significant. Strength of association was determined by the estimating odds ratio and their $95 \%$ confidence intervals.

\section{RESULTS}

Seventy percent of cases and $90 \%$ of control group belongs to 20-30 years of age range the mean BMI was higher in case $(30.6 \pm 5.1)$ group compared to that in control group $(23.91 \pm 3.7)$ but the difference between the two groups was not statistically significant. Mean fasting plasma glucose and mean 2- hours plasma glucose was significantly higher in case group in comparison to that in control group. The mean serum vitamin D level was lower in case 23.4 $(17.4 \pm 35.1)$ group compared to that in control group 29.7 $(15.4 \pm 39.8)$ and the difference between the two groups was statistically significant $(p \leq 0.001)$. Regarding the comparison of serum vitamin D between GDM and normal pregnant women the mean of sufficient level of vitamin $D$ was more in control group $(36.4 \pm 2.07)$ than that of case group (23.5 \pm 0.69$)$. This finding was statistically significant $(\mathrm{p}=0.041)$. Mean of insufficient level of vitamin $\mathrm{D}$ was lower in case $(35.05 \pm 3.50)$ group than that of control (24.6 \pm 3.1$)$ group. This finding was statistically significant $(\mathrm{p}=0.021)$. The comparisons of serum vitamin $\mathrm{D}$ between GDM and normal pregnant women shows sufficient level of vitamin D was more in control group $(66.7 \%)$ than that of case $(26.1 \%)$ group. Insufficient level of vitamin D was higher in case $(73.3 \%)$ group than that of control $(33.3 \%)$ group. These findings were statistically significant $(\mathrm{p}=0.021)$. Respondents with insufficient level of vitamin D have 3.1 times more chance to develop GDM. $(\mathrm{OR}=3.1 ; 95 \% \mathrm{CI}=2.1-8.60)$.

Table 1: Distribution of the study patients by age ( case $=30$, control $=30$ ).

\begin{tabular}{|c|c|c|c|c|c|}
\hline \multirow{2}{*}{$\begin{array}{l}\text { Age } \\
\text { group } \\
\text { (years) }\end{array}$} & \multicolumn{2}{|c|}{ With GDM } & \multicolumn{2}{|c|}{ Without GDM } & \multirow{2}{*}{ P value } \\
\hline & $\mathbf{N}=\mathbf{3 0}$ & $\%$ & $\mathbf{N}=\mathbf{3 0}$ & $\%$ & \\
\hline$<20$ & 0.0 & 0.0 & 0.0 & 0.0 & \multirow{3}{*}{0.58} \\
\hline $20-30$ & 21 & 70.0 & 27 & 90.0 & \\
\hline$>\mathbf{3 0}$ & 9 & 30.0 & 3 & 10.0 & \\
\hline
\end{tabular}

Table 2: Body mass index of the respondents (case $=30$, control=30).

\begin{tabular}{llll}
$\begin{array}{l}\text { Body mass } \\
\text { index } \\
\left(\mathrm{kg} / \mathrm{m}^{2}\right)\end{array}$ & $\begin{array}{l}\text { With } \\
\text { GDM, } \\
(\mathrm{n}=30),\end{array}$ & $\begin{array}{l}\text { Without } \\
\text { GDM, } \\
(\mathrm{n}=30),\end{array}$ & $\begin{array}{l}\text { P } \\
\text { value }\end{array}$ \\
BMI & $30.6 \pm 5.1$ & $23.91 \pm 3.7$ & 1.201 \\
\hline
\end{tabular}


Table 3: Mean of serum vitamin $D$ level between GDM and non-diabetic pregnant women (case $\mathbf{n}=\mathbf{3 0}$, control $n=30$ ).

\begin{tabular}{|llll|}
$\begin{array}{l}\text { Serum } \\
\text { biochemical } \\
\text { parameters }\end{array}$ & $\begin{array}{l}\text { With } \\
\text { GDM, } \\
\text { (n=30), } \\
\text { Mean } \pm \text { SD }\end{array}$ & $\begin{array}{l}\text { Without } \\
\text { GDM, } \\
(\mathbf{n = 3 0}), \\
\text { Mean } \pm \text { SD }\end{array}$ & $\begin{array}{l}\text { P } \\
\text { value }\end{array}$ \\
\hline $\begin{array}{l}\text { Fasting } \\
\text { plasma } \\
\text { glucose } \\
\text { (mmol/L) }\end{array}$ & $5.1 \pm 1.5$ & $4.1 \pm 0.6$ & $<0.001$ \\
\hline $\begin{array}{l}\text { 2-hours } \\
\text { plasma } \\
\text { glucose } \\
\text { (mmol/L) }\end{array}$ & $8.0 \pm 0.6$ & $5.6 \pm 0.8$ & $<0.001$ \\
$\begin{array}{l}\text { Serum } \\
\text { vitamin D } \\
\text { (ng/ml) }\end{array}$ & 23.4 & & \\
\hline
\end{tabular}

Table 4: Comparison of serum vitamin $D$ between GDM and normal pregnant women (case $n=30$, control $\mathbf{n}=30$ ).

\begin{tabular}{|c|c|c|c|c|c|}
\hline \multirow[t]{2}{*}{$\begin{array}{l}\text { Vitamin } \\
\text { D level } \\
(\mathrm{ng} / \mathrm{ml})\end{array}$} & \multicolumn{2}{|c|}{$\begin{array}{l}\text { With GDM, } \\
(\mathrm{n}=30)\end{array}$} & \multicolumn{2}{|c|}{$\begin{array}{l}\text { Without GDM, } \\
(\mathrm{n}=30)\end{array}$} & \multirow[t]{2}{*}{$\begin{array}{l}\mathbf{P} \\
\text { value }\end{array}$} \\
\hline & $\begin{array}{l}N \\
(\%)\end{array}$ & $\begin{array}{l}\text { Mean } \pm \\
\text { SD }\end{array}$ & $\begin{array}{l}N \\
(\%)\end{array}$ & $\begin{array}{l}\text { Mean } \pm \\
\text { SD }\end{array}$ & \\
\hline $\begin{array}{l}\text { Sufficie } \\
\text { nt (>30 } \\
\text { ng/ml) }\end{array}$ & $\begin{array}{l}8 \\
(26.1)\end{array}$ & $\begin{array}{l}23.50 \pm \\
0.69\end{array}$ & $\begin{array}{l}20 \\
(66.7)\end{array}$ & $\begin{array}{l}36.40 \pm \\
2.07\end{array}$ & 0.041 \\
\hline $\begin{array}{l}\text { Insuffici } \\
\text { ent (<30 } \\
\text { ng/ml) }\end{array}$ & $\begin{array}{l}22 \\
(73.3)\end{array}$ & $\begin{array}{l}35.05 \pm \\
3.50\end{array}$ & $\begin{array}{l}10 \\
(33.3)\end{array}$ & $\begin{array}{l}24.6 \pm \\
3.1\end{array}$ & 0.021 \\
\hline
\end{tabular}

Table 5: Odds ratios (OR) and $95 \%$ confidence intervals (CI) for gestational diabetes (GDM) according to maternal plasma 25 -hydroxyvitamin D 25 $(\mathrm{OH}) \mathrm{D}$ concentrations in pregnancy.

\begin{tabular}{|c|c|c|c|c|}
\hline $\begin{array}{l}\text { Serum } \\
\text { vitamin D } \\
\text { (ng/ml) }\end{array}$ & $\begin{array}{l}\text { With } \\
\text { GDM, } \\
\text { n }(\%)\end{array}$ & $\begin{array}{l}\text { Without } \\
\text { GDM, } \\
\text { n }(\%)\end{array}$ & $\begin{array}{l}P \\
\text { value }\end{array}$ & $\begin{array}{l}\text { OR } \\
(95 \% \\
\text { CI })\end{array}$ \\
\hline $\begin{array}{l}\text { Sufficient } \\
\text { (>30 ng/ml) }\end{array}$ & $8(26.1)$ & $20(66.7)$ & \multirow{2}{*}{0.03} & \multirow{2}{*}{$\begin{array}{l}3.1 \\
(1.20 \\
-8.60)\end{array}$} \\
\hline $\begin{array}{l}\text { Insufficient } \\
(<30 \mathrm{ng} / \mathrm{ml})\end{array}$ & $\begin{array}{l}22 \\
(73.3)\end{array}$ & $10(33.3)$ & & \\
\hline
\end{tabular}

\section{DISCUSSION}

In this study, it was observed that most of patients belonged to age 20-30 years. Our study is consistent with the findings that the prevalence of vitamin D insufficiency among the study population was found $80 \%$ of the study population belongs to 31-50 years of age range which was not similar. ${ }^{21}$ Lowest mean vitamin D level was found in the younger age group 18-30 years (mean-12.63, SD4.62). $95.3 \%$ of study population was Muslim which is almost similar to this study. ${ }^{22}$ It was observed that majority of the participants $83.3 \%$ of control group and $63.3 \%$ of case group were at the period of 30 weeks of gestation. The mean BMI was higher in case $(30.6 \pm 5.1)$ group compared to that in control group $(23.91 \pm 3.7)$ but the difference between the two groups was not statistically significant. An association between vitamin D and body fat has been found in several studies. ${ }^{23,24}$ As body fat and weight gain are risk factors for GDM, it is important to adjust for body fat as a confounder of the association between vitamin D and GDM. ${ }^{25}$ Asians are known to have a body composition with more visceral and central fat and more fat per BMI unit compared with Western subjects which contribute to an increased insulin resistance, particularly seen in South Asians. ${ }^{26}$ The mean serum vitamin D level was lower in case $23.4(17.4 \pm 35.1)$ group compared to that in control group $29.7(15.4 \pm 39.8)$ and the difference between the two groups was statistically significant $(\mathrm{p} \leq 0.001)$. Our findings of the association of low maternal plasma vitamin D concentrations in pregnancy with GDM is consistent with findings from three separate meta-analyses of published studies emphasizing the role of vitamin D. ${ }^{27,28}$ An increase in the risk of GDM by $40-60 \%$ in women with vitamin D deficiency during the third trimester of pregnancy has also been previously observed. ${ }^{27-30}$ In a study showed a potentially beneficial role for vitamin $\mathrm{D}$ in reducing the risk of GDM (RR: $0.61,95 \%$ CI $0.34-0.83$ ) in 2,643 pregnant women. ${ }^{31}$ Cross sectional studies conducted by Clifton-Bligh et al at mid-pregnancy demonstrated a poor vitamin D status as the risk factor for poor glucose control. ${ }^{32}$ The current study showed a negative correlation between the vitamin D concentration and GTT values which is in alignment with the findings of Maghbooli et al confirming the association of poor vitamin D status and the risk of GDM through a negative correlation between serum vitamin D and fasting plasma glucose. ${ }^{33}$ Mean of sufficient level of vitamin D was more in control group (36.4 \pm 2.70$)$ than that of case $(23.5 \pm 0.69)$ group. This finding was statistically significant $(\mathrm{p}=0.041)$. Mean of insufficient level of vitamin D was lower in case $(35.05 \pm 3.50)$ group than that of control $(24.6 \pm 3.1)$ group. This finding was statistically significant $(p=0.021)$. The risk of GDM in relation with low level of vitamin $\mathrm{D}$ was measured by odds ratio with $95 \%$ confidence interval and it was found 3.1 . Respondents with insufficient level of vitamin D had 3.1 times more chance to develop GDM (OR=3.1; 95\% $\mathrm{CI}=1.20-8.60)$. A $5-\mathrm{ng} / \mathrm{mL}$ increase in total $25[\mathrm{OH}] \mathrm{D}$ concentration was associated with a $14 \%$ reduction in GDM risk (OR 0.86 [95\% CI 0.77, 0.97]). Women with total 25[OH]D deficiency had a 1.97-fold increased risk of GDM compared with women who were total $25[\mathrm{OH}] \mathrm{D}$ sufficient $(\geq 30 \mathrm{ng} / \mathrm{mL}) \quad[95 \%$ CI $1.12,3.47]$ in the unadjusted model. Women in the lower three quartiles for total $25[\mathrm{OH}] \mathrm{D}$ concentration had higher risk of GDM compared with women in the highest quartile in unadjusted models $(p=0.013) .{ }^{34}$ Our findings are similar to some previous studies that investigated vitamin $\mathrm{D}$ status and GDM risk, but were different from others. ${ }^{34-38}$ Previously, in a nested case-control study conducted among 57 GDM cases and 114 controls, our research group reported that vitamin D deficiency was associated with a 2.66-fold 
increased risk of subsequent GDM [95\% CI 1.01, 7.02] ${ }^{34}$ Three independent meta-analyses of observational studies reported 38-61\% higher risk of GDM among women with vitamin $\mathrm{D}$ deficiency (total $25[\mathrm{OH}] \mathrm{D}<50$ $\mathrm{nmol} / \mathrm{L}) .{ }^{39}$ More recently, Lacroix reported that lower first trimester $25[\mathrm{OH}] \mathrm{D}$ concentrations were associated with higher risk of developing GDM (OR 1.48 per decrease of one SD in 25[OH]D concentration, $\mathrm{p}=0.04) 14$. Baker et al reported that women with vitamin $\mathrm{D}$ deficiency, in early pregnancy, did not have a significantly higher risk of GDM compared with women who did not have vitamin D deficiency (OR 0.78 [95\% CI 0.22, 2.78]). ${ }^{36}$ Similarly, researchers did not observe associations of vitamin D deficiency with risk of GDM in other studies conducted in Korea, North England, and Australia. ${ }^{39,40}$ Recently, Zhou et al reported that the prevalence of GDM was higher among women with high 25[OH]D $(\geq 30 \mathrm{ng} / \mathrm{mL})$ concentrations compared with women in the low and medium groups (OR 1.02 [95\% CI 1.00, 1.03]). ${ }^{41}$ Notably, there have not been randomized control trials that were designed to examine associations of vitamin D status with risk of GDM.

\section{CONCLUSION}

Serum vitamin D level is reduced in pregnant women having GDM.

\section{Funding: No funding sources}

Conflict of interest: None declared

Ethical approval: The study was approved by the Institutional Ethics Committee

\section{REFERENCES}

1. National Institution of Health. Office of Dietary Supplements. 2010. Available at: http://books.nap.ed u/openbook.php.record_id=5776\&page. Accessed on October 5, 2010.

2. Holick MF. Vitamin D. The underappreciated Dlightful hormone that is important for skeletal and cellular health. Curr. Opin Endocrinol. Diabetes Obes. 2002;9:87-98.

3. Autier P, Boniol M, Pizot C, Mullie P. Vitamin D status and ill health: A systematic review. Lancet Diabetes Endocrinol. 2014;2:76-89.

4. Holick MF. Vitamin D: Importance in the prevention of cancers, type 1 diabetes, heart disease, and osteoporosis. Am J Clin Nutr. 2004;79:362-71.

5. Grover SR, Morley R. Vitamin D deficiency in veiled or dark-skinned pregnant women. Med J Aust. 2001;175:251-2.

6. Sachan A, Gupta R, Das V, Agarwal A, Awasthi PK, Bhatia V. High prevalence of vitamin D deficiency among pregnant women and their newborns in northern India. Am J Clin Nutr. 2005;81:1060-4.

7. Brannon PM. Vitamin D and adverse pregnancy outcomes: Beyond bone health and growth. Proc Nutr Soc. 2012;71:205-12.
8. Bener A, AL-Hamaq AOAA, Saleh NM. Association between vitamin D insufficiency and adverse pregnancy outcome: Global comparisons. Int J Womens Health. 2013;5:523-31.

9. Bodnar LM, Catov JM, Zmuda JM, Cooper ME, Parrott MS, Roberts JM et al. Maternal Serum 25Hydroxyvitamin D Concentrations Are Associated with Small-for-Gestational Age Births in White Women. J Nutr. 2010;140:999-1006.

10. Carrapato $\mathbf{M}$. The offspring of gestational diabetes. J Perinat Med. 2003;31:5-11.

11. Sivaraman SC, Vinnamala S, Jenkins D. Gestational Diabetes and Future Risk of Diabetes. J Clin Med Res. 2013;5:92-6.

12. Javaid M, Crozier S, Harvey N, Gale C, Dennison E, Boucher B. Maternal vitamin D status during pregnancy and childhood bone mass at age 9 years: a longitudinal study. Lancet. 2006;367:36-43.

13. Park S, Yoon HK, Ryu HM, Han YJ, Lee SW, Park BK. Maternal vitamin D deficiency in early pregnancy is not associated with gestational diabetes mellitus development or pregnancy outcomes in Korean pregnant women in a prospective study. J Nutr Sci Vitaminol. 2014;60:269-75.

14. Lacroix M, Battista MC, Doyon M, Houde G, Menard J, Ardilouze JL et al. Lower vitamin D levels at first trimester are associated with higher risk of developing gestational diabetes mellitus. Acta Diabetol. 2014;51:609-16.

15. Zhang C, Qiu C, Hu FB, David RM, van Dam RM, Bralley A. Maternal plasma 25-hydroxyvitamin D concentrations and the risk for gestational diabetes mellitus. PLoS ONE. 2008;3:e3752.

16. Zhang MX, Pan GT, Guo JF, Li BY, Qin LQ, Zhang ZL. Vitamin D deficiency increases the risk of gestational diabetes mellitus: a meta-analysis of observational studies. Nutrients. 2015;7:8366-75.

17. Ritu G, Ajay G. Vitamin D deficiency in India: prevalence, causalities and interventions. Nutrients. 2014;6:729-75.

18. Shahgheibi S, Farhadifar F, Pouya B. The effect of vitamin D supplementation on gestational diabetes in high-risk women: Results from a randomized placebo-controlled trial. J Res Med Sci. 2016;2016:21-2.

19. Dwarkanath $\mathrm{P}$, Vinotha $\mathrm{P}$, Thomas $\mathrm{T}$, Joseph $\mathrm{S}$, Thomas A, Shirley G et al. Relationship of Early Vitamin D Concentrations and Gestational Diabetes Mellitus in Indian Pregnant Women. Front Nutr. 2019;6:116.

20. Jamilian M, Samimi M, Ebrahimi FA. The effects of vitamin D and omega-3 fatty acid co-supplementation on glycemic control and lipid concentrations in patients with gestational diabetes. J Clin Lipidol. 2017;11:459-68.

21. American Diabetes Association. Gestational diabetes mellitus. Diabetes Care. 2004;27:S88-90.

22. Chowdhury NA, Hossain MZ, Mia MM, Hoque S, Chowdhury NA, Sultana R, Nizhu LN. Vitamin D 
Status of Adults in the Outpatient Department in Bangladesh. J Dhaka Med Coll. 2018;27(1):94-7.

23. Wortsman J, Matsuoka LY, Chen TC, Lu Z, Holick MF. Decreased bioavailability of vitamin $D$ in obesity. Am J Clin Nutr. 2000;72(3):690-3.

24. Cheng S, Massaro JM, Fox CS. Adiposity, cardiometabolic risk, and vitamin D status: the Framingham Heart Study. Diabetes. 2010;59(1):2428.

25. Metzger BE, Buchanan TA, Coustan DR. Summaryn and recommendations of the Fifth International Workshop-Conference on Gestational Diabetes Mellitus. Diabetes Care. 2007;30(2):S251-60.

26. Jenum AK, Sommer C, Sletner L, Morkrid K, Baerug A, Mosdol A. Adiposity and hyperglycaemia in pregnancy and related health outcomes in European ethnic minorities of Asian and African origin: a review. Food Nutr Res. 2013;57(1):18889.

27. Aghajafari F, Nagulesapillai T, Ronksley PE, Tough SC, O'Beirne M, Rabi DM. Association between maternal serum 25-hydroxyvitamin D Level and pregnancy and neonatal outcomes: systematic review and meta-analysis of observational studies. Br Med J. 2013;346:f1169.

28. Wei SQ, Qi HP, Luo ZC, Fraser WD. Maternal vitamin D status and adverse pregnancy outcomes: a systematic review and meta-analysis. J Matern Fetal Neonatal Med. 2013;26:889-99.

29. Hu L, Zhang Y, Wang X. Maternal Vitamin D Status and risk of gestational diabetes: a meta-analysis. Cell Physiol Biochem. 2018;45:291-300.

30. Poel YH, Hummel P, Lips P, Stam F, Van der Ploeg T, Simsek S. Vitamin D and gestational diabetes: a systematic review and meta-analysis. Euro J Internal Med. 2012;23:465-9.

31. Roth DE, Leung M, Mesfin E, Qamar H, Watterworth J, Papp E. Vitamin D supplementation during pregnancy: state of the evidence from a systematic review of randomised trials. BMJ. 2017;359:j5237.

32. Clifton-Bligh RJ, McElduff P, McElduff A. Maternal vitamin D deficiency, ethnicity and gestational diabetes. Diabet Med. 2008;24:27-32.

33. Maghbooli Z, Hossein-Nezhad A, Karimi F. Correlation between vitamin D3 deficiency and insulin resistance in pregnancy. Diabetes Metab Res Rev. 2008;24:27-32.

34. Arnold DL, Enquobahrie DA, Qiu C, Huang J, Grote N, Vander Stoep N et al. Wiliams Early Pregnancy
Maternal Vitamin D Concentrations and Risk of Gestational Diabetes Mellitus. Paediatr Perinat Epidemiol. 2015;29(3):200-10.

35. McManus R, Summers K, De Vrijer B, Cohen N, Thompson A, Giroux I. Maternal, umbilical arterial and umbilical venous 25-hydroxyvitamin $\mathrm{D}$ and adipoctyokine concentrations in pregnancies with and without gestational diabetes. Clin Endocrinol. 2014;80:635-41.

36. Baker AM, Haeri S, Camargo CA, Stuebe AM, Boggess KA. First-trimester maternal vitamin D status and risk for gestational diabetes (GDM) a nested case-control study. Diabetes/Metabolism Research and Rev. 2012;28:164-8.

37. Park S, Yoon H-K, Ryu H-M, Han YJ, Lee SW, Park BK et al. Maternal vitamin D deficiency in early pregnancy is not associated with gestational diabetes mellitus development or pregnancy outcomes in Korean pregnant women in a prospective study. J Nutr Sci Vitaminol. 2014;60:269-75.

38. Schneuer FJ, Roberts CL, Gulbert C, Simpson JM, Algert CS, Khambalia AZ et al. Effects of maternal serum 25-hydroxyvitamin D concentations in the first trimester on subsequent pregnancy outcomes in an Australian population. Am J Clin Nutr. 2014;99:28795.

39. Whitelaw DC, Scally AJ, Tuffnell DJ, Davies TJ, Fraser WD, Bhopal RS et al. Associations of circulating calcium and 25-hydroxyvitamin D with glucose metabolism in pregnancy: a cross-sectional study in European and South Asian women. J Clin Endocrinol Meta. 2014;99:938-46.

40. Wei S-Q, Qi H-P, Luo Z-C, Fraser WD. Maternal vitamin $\mathrm{D}$ status and adverse pregnancy outcomes: a systematic review and meta-analysis. J Maternal-fetal Neonatal Med. 2013;26:889-99.

41. Zhou J, Su L, Liu M, Liu Y, Cao X, Wang Z et al. Associations between 25-hydroxyvitamin D levels and pregnancy outcomes: a prospective observational study in southern China. Eur J Clin Nutr. 2014;68:925-30.

Cite this article as: Mahmood S, Pervin HH, Yousuf $\mathrm{S}$. Association of serum vitamin D levels with gestational diabetes mellitus. Int J Reprod Contracept Obstet Gynecol 2021;10:2198-202. 